\title{
SISTEM MANAJEMEN PENGELOLAHAN HOTEL UMM INN BERBASIS WEBSITE
}

\author{
Muhammad Ghulam Asshokin ${ }^{1}$, Deddy Kusbianto Purwoko Aji ${ }^{2}$, Ariadi Retno Trihayati Ririd ${ }^{3}$ \\ 1,2 Jurusan Teknik Elektro, Program Studi Teknik Informatika, Politeknik Negeri Malang \\ 19hulam1492@gmail.com, ${ }^{2}$ deddy_kusbianto@polinema.ac.id, ${ }^{3}$ retno7ara@gmail.com
}

\begin{abstract}
Abstraksi
Perkembangan teknologi informasi membuat banyak perusahaan di bidang administrasi perhotelan mulai mengembangkan sistem yang menggunakan teknologi informasi. Salah satu cara adalah dengan menggunakan aplikasi berbasis web. Pemesanan sistem informasi berbasis web dikembangkan di Hotel UMM INN. Sistem ini mengelola data pemesanan check-in dan check-out proses. Sistem informasi reservasi dikembangkan oleh model air terjun, dan dibangun dengan PHP dan PhpMyAdmin sebagai alat untuk membantu mengelola database MySQL dan editor teks Dreamweaver Sistem informasi reservasi dapat memberikan kemudahan kepada resepsionis hotel dan pelanggan dalam membuat reservasi. Selain itu, pengunjung juga dapat memperoleh semua informasi dan berita tentang fasilitas yang ada di Hotel UMM INN.

Hotel ini menawarkan berbagai fasilitas untuk memastikan konsumen menghabiskan waktu dengan spesial. Manfaatkan wi-fi di tempat-tempat umum, lift, transfer bandara/hotel, restoran yang disediakan hotel. Televisi, pembuat kopi/teh, ruangan bebas rokok, fasilitas menyetrika, ruang duduk dapat ditemukan di setiap kamar. Untuk meningkatkan jumlah bermalam para tamu, hotel ini menawarkan fasilitas rekreasi seperti taman. Suasana yang ramah dan pelayanan yang terbaik adalah apa yang dapat konsumen harapkan selama tinggal di UMM Inn.
\end{abstract}

Kata kunci: waterfall, manajemen, Sistem Informasi.

\section{Pendahuluan}

Di era modern ini masyarakat banyak memilih liburan untuk ke luar kota, untuk itu pasti dibutuhkan penginapan untuk beristirahat. Turis mancaneagara maupun lokal banyak memilih menginap di hotel sebagai tempat istirahat. Maka dari itu hotel membutuhkan akses seperti web untuk memasarkan dan memberi informasi pada masayarakat atau konsumen yang akan memesan kamar dan mengetahui tentang info hotel.

Penelitian yang berhubungan dengan reservasi hotel sudah dilakukan oleh Pepi Siswhar Ismail (2011) dalam penelitian yang berjudul Sistem Informasi Reservasi Kamar Hotel Berbasis Website. Sistem informasi reservasi berbasis web dikembangkan di Hotel Karlita, sistem tersebut mengolah data pemesanan kamar baik proses check-in dan check-out maupun proses penghitungan pendapatan sewa kamar per bulan. Sistem informasi reservasi dikembangkan dengan waterfall model, dan dibangun dengan bahasa pemrograman PHP dan PhpMyAdmin sebagai sebuah tools untuk membantu mengelola basis data MySql serta text editor Notepad++. Sistem informasi reservasi dapat memberikan kemudahan bagi receptionist dan pelanggan hotel dalam melakukan pemesanan kamar.
Selain itu pengunjung juga dapat memperoleh segala informasi fasilitas dan berita yang ada di Hotel Karlita.

Dari permasalahan tersebut, untuk membantu pihak hotel memberikan info tentang hotel dan pemesanan kamar untuk user dengan mudah dan efisien. Salah satu cara adalah dengan menggunakan aplikasi berbasis web. Pemesanan sistem informasi berbasis web dibuat di Hotel UMM INN. Sistem ini mengelola data pemesanan checkin dan check-out proses. Sistem informasi reservasi dikembangkan oleh model air terjun, dan dibangun dengan PHP dan PhpMyAdmin sebagai alat untuk membantu mengelola database MySQL dan editor teks Dreamweaver Sistem informasi reservasi dapat memberikan kemudahan kepada resepsionis hotel dan pelanggan dalam membuat reservasi. Selain itu, pengunjung juga dapat memperoleh semua informasi dan berita tentang fasilitas yang ada di Hotel UMM INN.

\section{Teori Dasar}

\section{A. Sistem Informasi}

Sistem informasi merupakan sistem, yang berisi jaringan Sistem Pengolahan Data, yang dilengkapi dengan kanal-kanal komunikasi yang 
digunakan dalam sistem organisasi data. Elemen proses dari sistem antara lain mengumpulkan data, mengelola data yang tersimpan, menyebarkan informasi.

Keberadaan sistem informasi diperlukan organisasi untuk mendampingi proses-proses bisnis dari organisasi. Contohnya, proses penjualan supermarket didampingi oleh sistem informasi penjualan, yang mencatat pengumpulan data dan informasi tentang penjualan (Witarto,2004:20).

\section{B. Waterfall}

Menurut Ian Sommerville (2011, p30-31), tahapan utama dari waterfall model langsung mencerminkan aktifitas pengembangan dasar. Terdapat 5 tahapan pada waterfall model, yaitu requirement analysis and definition, system and software design, implementation and unit testing, integration and system testing, dan operation and maintenance.

\section{$C$. Metode Penelitian}

Berikut adalah penjelasan dari tahapantahapan metode waterfall :

- Requirement Analysis and Definition

Merupakan tahapan penetapan fitur, kendala dan tujuan sistem melalui konsultasi dengan pengguna sistem. Semua hal tersebut akan ditetapkan secara rinci dan berfungsi sebagai spesifikasi sistem.

\section{- $\quad$ System and Software Design}

Dalam tahapan ini akan dibentuk suatu arsitektur sistem berdasarkan persyaratan yang telah ditetapkan. Dan juga mengidentifikasi dan menggambarkan abstraksi dasar sistem perangkat lunak dan hubungan-hubungannya.

\section{- Implementation and Unit Testing}

Dalam tahapan ini, hasil dari desain perangkat lunak akan direalisasikan sebagai satu set program atau unit program. Setiap unit akan diuji apakah sudah memenuhi spesifikasinya.

\section{- Integration and System Testing}

Dalam tahapan ini, setiap unit program akan diintegrasikan satu sama lain dan diuji sebagai satu sistem yang utuh untuk memastikan sistem sudah memenuhi persyaratan yang ada. Setelah itu sistem akan dikirim ke pengguna sistem.

\section{- Operation and Maintenance}

Dalam tahapan ini, sistem diinstal dan mulai digunakan. Selain itu juga memperbaiki error yang tidak ditemukan pada tahap pembuatan. Dalam tahap ini juga dilakukan pengembangan sistem seperti penambahan fitur dan fungsi baru.

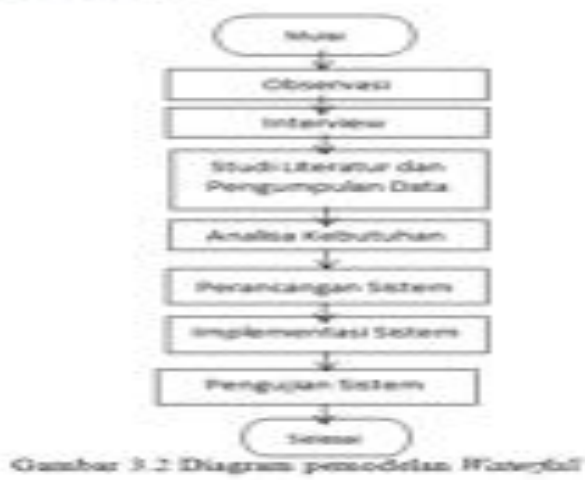

Gambar 2.1 Waterfall menurut Ian Sommerville

\section{Perancangan Sistem}

\section{A. Use Case Diagram}

Menurut Dan Pilone \& Neil Pitman (2005, p115-128), Use case adalah cara untuk menangkap fungsionalitas sistem dan persyaratan dalam UML. Use case diagram terdiri dari potongan-potongan yang bernama fungsi (menggunakan use case), orang-orang atau hal-hal memanggil fungsi (aktor).

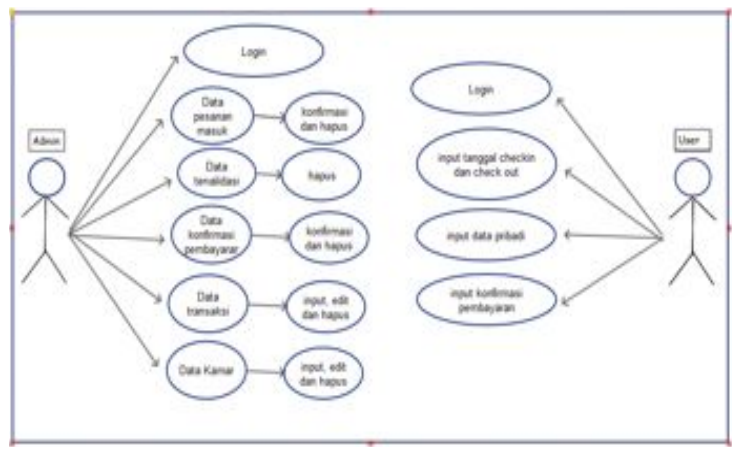

Gambar 3.2 use case

\section{B. Work Breakdown Structure}

Menurut schwalbe (2004, p157), Work Breakdown Structure (WBS) adalah sebuah analisa yang berorientasi keluar dari pekerjaan yang terlibat dalam proyek yang mendefinisikan keseluruhan ruang lingkup proyek. Work Breakdown Structure (WBS) merupakan dokumen dasar dalam menajemen proyek 
karena menydiakan dasar untuk perencanaan dan pengaturan jadwal proyek, biaya dan perubahan. Seorang yang ahli dalam manajemen proyek percaya bahwa kegiatan yang tidak seharusnya dilakukan dalam proyek bilamana kegiatan tersebut tidak termasuk dalam Work Breakdown Structure (WBS).

Gambar di bawah ini adalah tentang work breakdown structure sistem manajemen pengelolahan hotel UMM INN berbasis website :

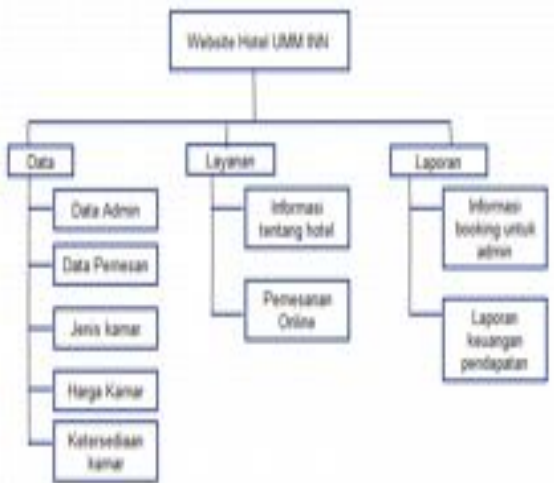

Gambar 3. 3. Work breakdown System C. Flowchart

KETERANGAN GAMBAR PADA FLOWCHART.
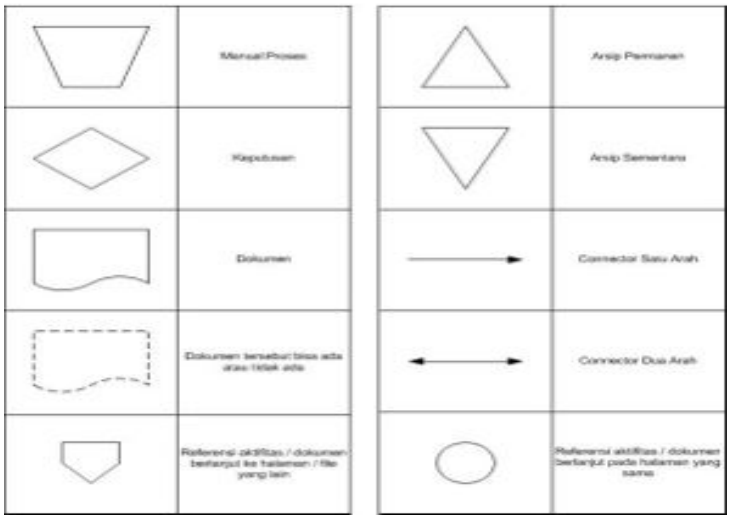

Gambar 3.4 Keterangan Flowchart

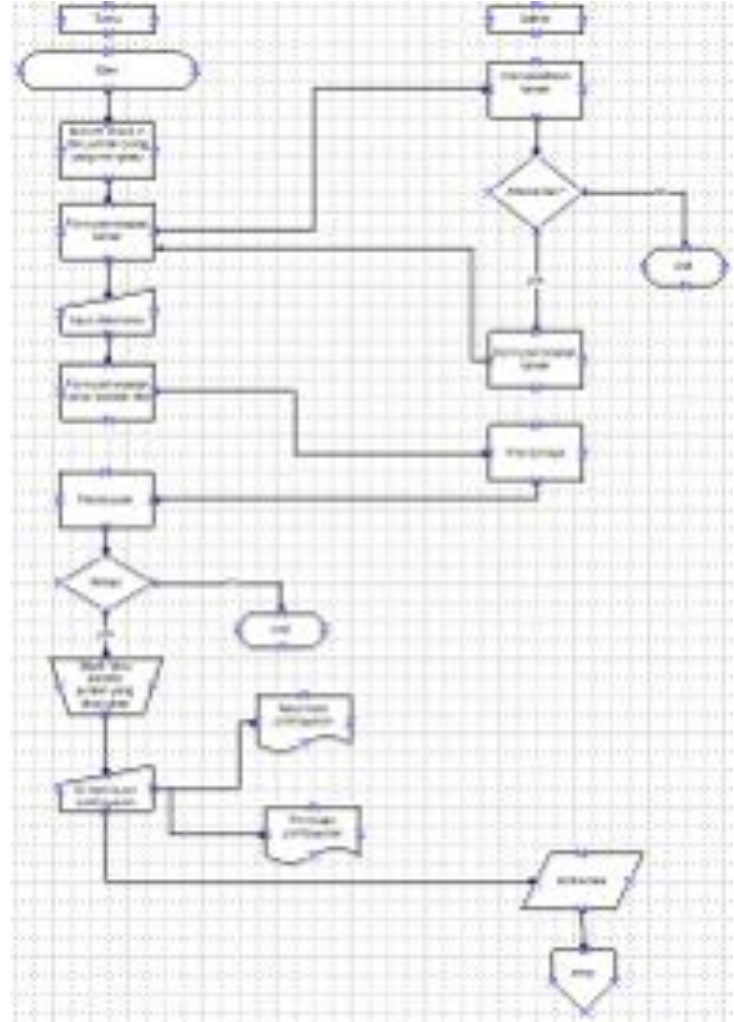

Gambar 3.5 Flowchar sistem

\section{Hasil dan Pembahasan}

\subsection{Tampilan untuk user}

\section{Halaman Utama}

Setelah user membuka alamat hotel akan mucul halaman dibawah ini.

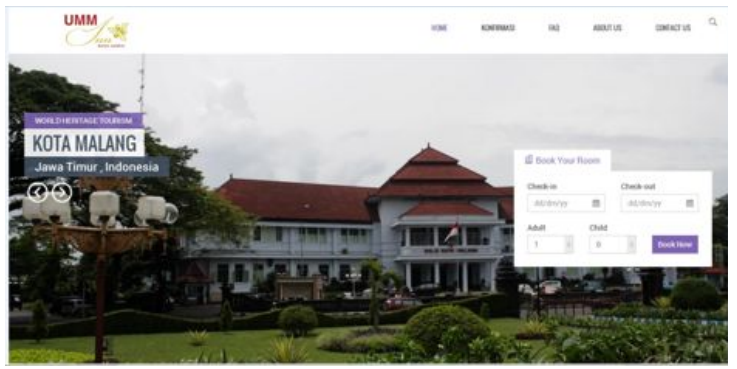

Gambar 4.1 Halaman Utama

2. Tampilan awal booking

Pilih tanggal masuk, tanggal keluar, pilih banyaknya dewasa dan banyaknya anak.

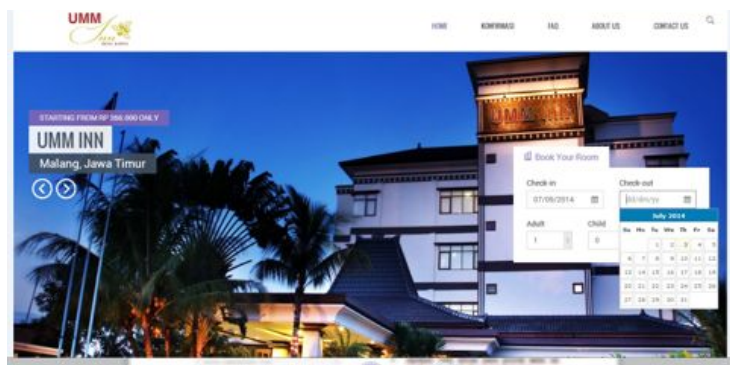

Gambar 4.2 tampilan awal booking 


\section{Pilihan kamar}

Pilih kamar yang ingin dipesan, harga weekdays dan weekend berbeda sistem yang menentukan termasuk kategori harga apa pada waktu pemesan atau user membooking kamar tersebut.

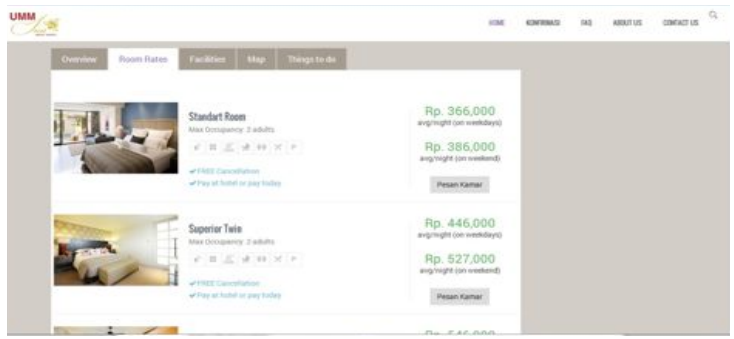

\section{Gambar 4.3 Pilihan kamar}

\section{Pengisian data pemesan}

Gambar dibawah adalah pengisian data yang perlu diisi oleh user atau pemesan.

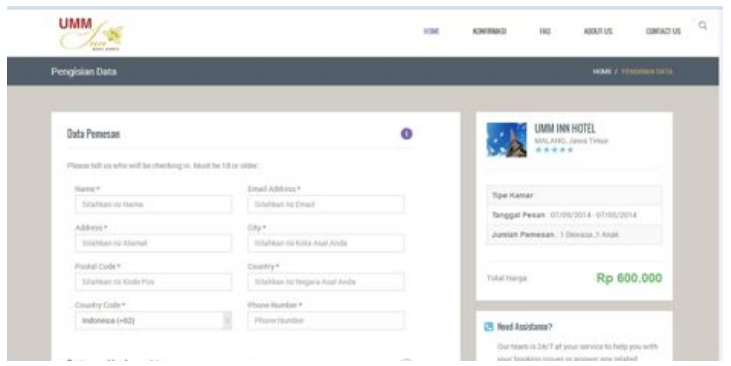

Gambar 4.4 Pengiusian data pemesan

5. Hasil booking user

Gambar dibawah merupakan tampilan hasil booking oleh user dan user mendapat kode booking yang telah ditentukan oleh sistem.

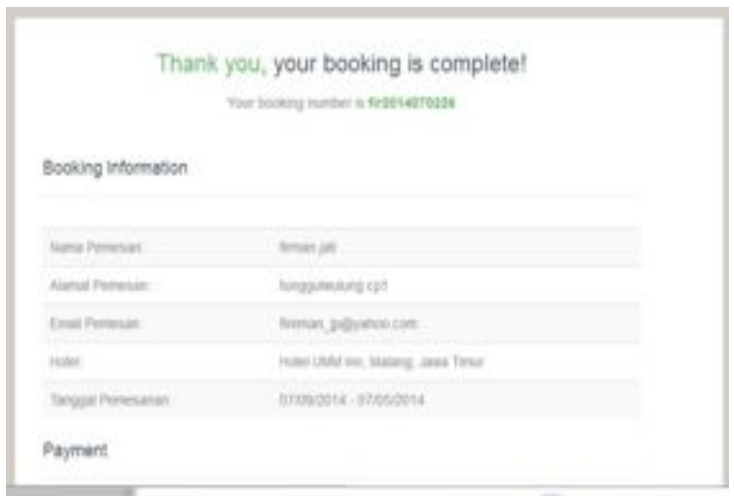

\section{Gambar 4.5 Hasil booking}

6. Konfimasi pembayaran

Gambar dibawah merupakan tampilan untuk user yang telah mentrasfer uang untuk membooking kamar yang telah dipilih sebelumnya.

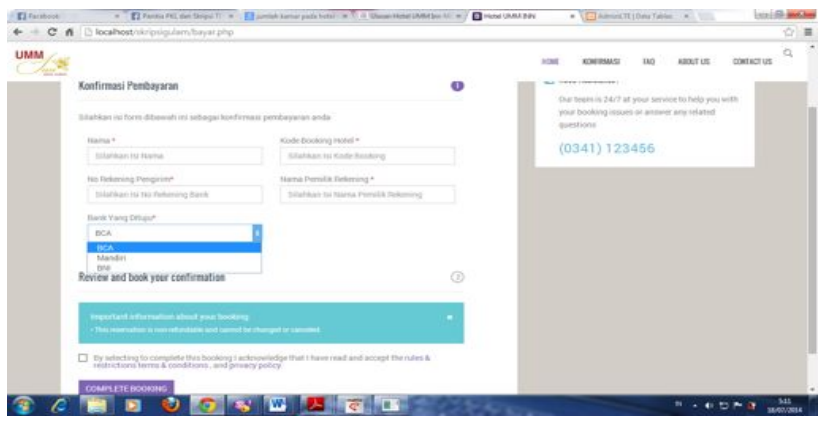

Gambar 4.6 konfirmasi pembayaran

\subsection{Tampilan untuk admin}

\section{Login admin}

Admin harus login terlebih dahulu user name dan password telah disediakan.

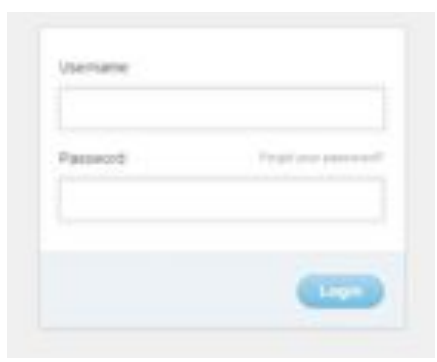

Gambar 4.2 Login admin

\section{Setelah login}

Setelah login admin dapa memilih data yang akan dikelolah apakah pemesan masuk, konfirmasi pembayaran dan pemesanan tervalidasi.

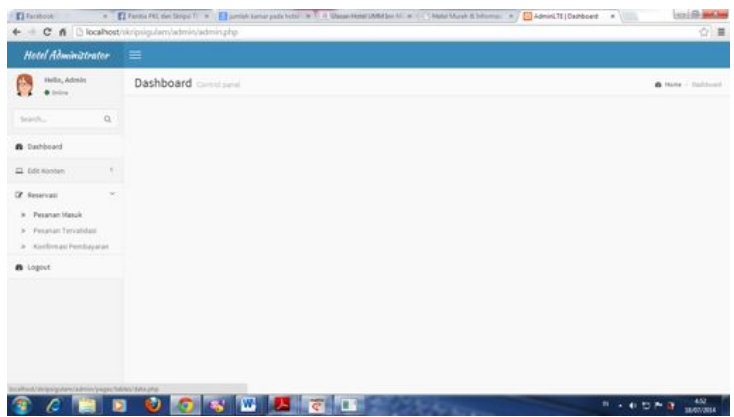

\section{Gambar 4.3 Setelah login}

3. Data pemesan masuk

Data pemesan masuk ini data user yang telah melakukan booking dan belum dikonfirmasi karena belum melakukan konfirmasi pembayaran. 


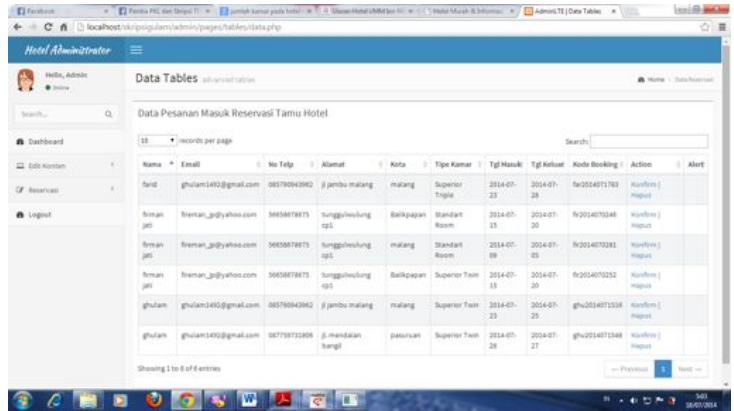

Gambar 4.4 Data pemesan masuk

\section{Data konfirmasi pembayaran}

Data konfirmasi pembayaran yang dilakukan oleh user apabila sudah melakukan transfer ke rekening hotel yang sudah disediakan.

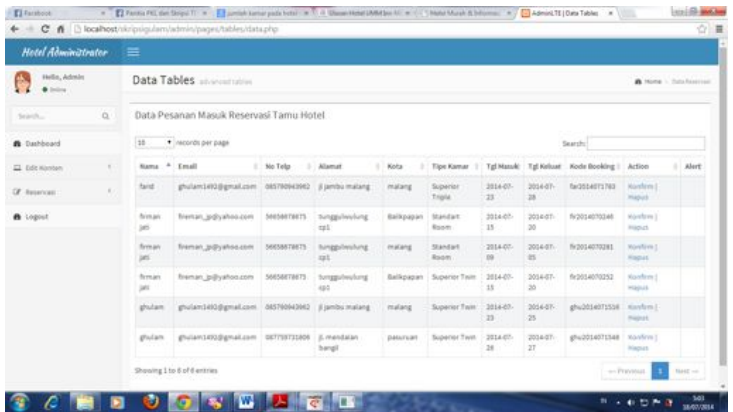

Gambar 4.5 Data konfirmasi pembayaran

\section{Data tervalidasi}

Gambar dibawah merupakan data yang harus dikelolah oleh admin apabila pemesan yang telah membayar dan melakukan konfirmasi pembayaran akan di konfirmasi dan masuk ke data tervalidasi atau pemesan telah komplit memesan kamar yang disediakan.

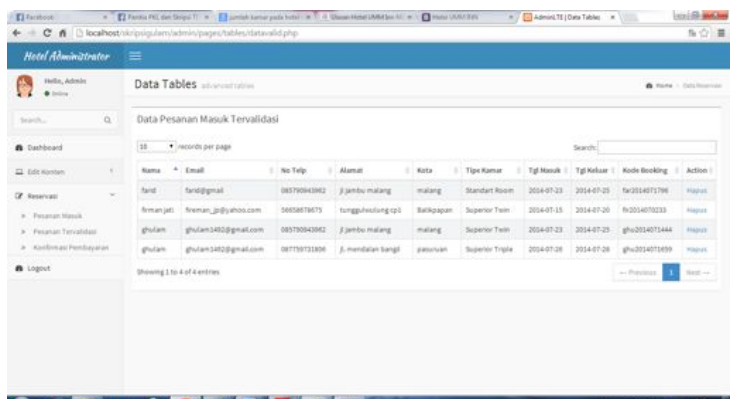

Gambar 4.6 Data tervalidasi.

\section{Pembukuan}
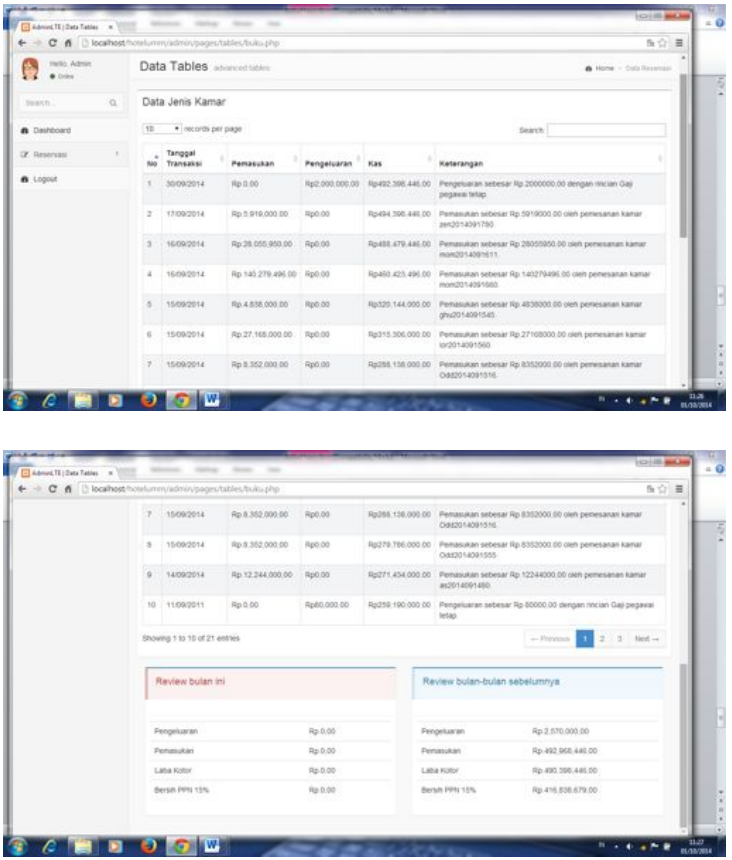

Gambar 4.5 Pembukuan

\section{Kesimpulan dan Saran}

\subsection{Kesimpulan}

Berdasarkan pembahasan pada bagian sebelumnya dapat ditarik beberapa kesimpulan, yaitu:

a. User tidak perlu login untuk mengunjungi website

b. Di dalam sistem ini juga disediakan halaman admin yang digunakan untuk memanage data yang ada di database server, sehingga proses memanage database lebih mudah dilakukan.

c. User dapat mengakses informasi melihat (view) tampilan dan melakukan booking room.

d. Untuk menampilkan atau mengupdate harga atau memutuskan bahwa user telah memesan yaitu admin (karyawan hotel).

e. Data yang diinputkan user harus asli.

\subsection{Saran}

Berdasarkan penelitian ini, ada beberapa hal yang disarankan, yaitu:

a. Tampilan aplikasi ini dapat dikembangkan yang lebih baik lagi untuk memudahkan user dalam mengoperasikannya.

b. Program ini dapat dikembangkan lebih lanjut dengan feature-feature yang lebih baik dan lebih praktis.

c. Aplikasi yang dibuat pada proyek akhir ini masih perlu untuk disempurnakan lagi. 
Nugroho, Adi. 2005. Rational

\section{Daftar Rujukan}

Witarto. 2004, Memahami Sistem

Informasi. Bandung: Informatika.

Sommerville, Ian. 8. Software Engineering. China Machine Press: China.

Aditama, Roki. 2012. Sistem Informasi Akademik Kampus Berbasis Web Dengan PHP. Lokomedia: Yogyakarta.

Syah Putra, Andry. 2004. Apache Web Server. Andi Offset: Yogyakarta.
Untuk Pemodelan Berorientasi

Objek. Informatika: Bandung.

Wahyuningsih, Sari. 2010.

Analisis Dan Perancangan Sistem Informasi Reservasi Online Berbasis Web Paada Hotel Rumah Palagan Yogyakarta. Informatika: Yogyakarta.

El Orbani, Auliya Izza. 2010. Terminologi Perhotelan: Jakarta.

Solichin, S.Kom, Achmad. 2010. Pemrograman Web dengan PHP dan MySQL. Universitas Budi Luhur: Jakarta Jogyanto, 2008. Analisis dan desain Sistem Informasi;8 